\title{
Administrative Restrictions in Ports: Practice of Crew Rotations During COVID-19 Pandemic
}

\section{Dmytro Luchenko*, Iurii Georgiievskyi**}

Luchenko, D., Georgiievskyi, Iu. (2021). Administrative Restrictions in Ports: Practice of Crew Rotations During COVID-19 Pandemic. Lex Portus, 7(3), 7-31. https://doi.org/10.26886/2524-101X.7.3.2021.1

*Doctor of Law, Professor, Department of Administrative Law, Yaroslav Mudryi National Law University (77, Pushkinska St., Kharkiv, Ukraine)

https://orcid.org/0000-0002-8666-2245

**Doctor of Law, Associate Professor, Head of the Scientific Department (Legal Support of Sectoral Innovative Development) of the Research Institute Innovative Development Legal Support of National Academy of Legal Sciences of Ukraine, Department of Administrative Law of Yaroslav Mudryi National Law University (77, Pushkinska St., Kharkiv, Ukraine) https://orcid.org/0000-0001-8014-7827

(c) \$( This work is licensed under a Creative Commons Attribution-

\section{ABSTRACT}

The article describes changes in imposing administrative restrictions for crew rotations in ports worldwide under the ongoing pandemic COVID19 situation. The first part of the article provides a brief overview of the impact of the COVID-19 pandemic on seafarers' well-being, considering 
the key role of seafarers in providing international trade, maritime security, and protection of the environment. The second part of the article describes the national and regional experience in addressing COVID-19 under crew rotations; highlights the main tendencies of strengthening/easing restrictions in seaports. The most typical restrictive administrative measures in crew rotations include dockage during the crew change off the port, ensuring social distancing, strict health monitoring, and the negative coronavirus test result, proof of being quarantined or staying on board given period. Furthermore, international organizations were considered efforts to minimize the impact of the pandemic on the stability of crew changes in ports. The recommended measures primarily focus on simplifying and stabilizing the crew changes procedures, including the unification of rotation procedures, adopting multilateral global management in the sphere, effective information exchange, etc. Lack of consolidated information about all administrative restrictions world's largest ports has become a complex issue. In that regard, the nonstate actors play an essential role in the information support of seafarers. However, such efforts can be enhanced by adding imperative rules, like daily updating of information by governments and implementing the control system with a possibility of sanctions implementation in ship detentions under Port State Control procedures.

The key words: administrative restrictions, seaports, COVID-19 pandemic, crew rotation, humanitarian crisis, hub ports.

\section{Introduction}

One of the most complex consequences of the ongoing COVID-19 pandemic for the maritime industry has become the problem of crew change (rotation) and the repatriation of crew members. Since the beginning of 2020, many ports around the world have imposed in their administration mechanisms the practice of absolute prohibition on crew rotation and removed the possibility for seafarers to come ashore and get some rest. This became a significant social, psychological and economic issue for many seafarers and their families both at sea and ashore, deprived them of livelihood, turned ships into "floating prisons" (Crew change crisis risks becoming forced labour epidemic as tragedy hits sixmonth mark on World Maritime Day. Press release). Administrative restrictions applied by port states to prevent the spread of new 
disease typically embraced international travel control measures that include:

- closing international borders to stop travelers crossing from one country to another;

- restricting travel to and from certain countries, particularly those with high infection levels;

- screening or testing travelers entering or leaving a country if they have symptoms or have been in contact with an infected person;

- quarantining newly-arrived travelers from another country, that is, requiring travelers to stay at home or in a specific place for a certain time (Burns et al., 2021).

It has become the most significant logistical challenge of the shipping industry for the last 50 years, which, by some estimates, may affect up to 1 million seafarers (COVID-19. Crew change crisis 2021). Gradual easing of quarantine restrictions, vaccination, organizational efforts of global, regional, and national institutions, gradual decline in the infection rate have enabled the practice of relatively stable crew changes in ports for a while. As a result, the repatriation and rotation situations have become more manageable. Nevertheless, crew changes now demand greater effort and cost than prior to the COVID-19 pandemic (De Beukelaer, 2021, p. 582).

Additionally, this problem was updated in early 2021 by the emergence of new coronavirus strains, concerns with recognition by governments of seafarers as a priority group for vaccination and making vaccines accessible for them, reductions in available flights, and limits on the issuing of visas and passports. The experience in implementing administrative mechanisms for safe crew rotations throughout the world is a valuable source, which may help identify the most successful, and makes proposals on how to improve and standardize them.

\section{Methodology}

The present research focusing on the efforts of the international community, regional and national regulators to meet challenges 
and demands of harmonization and standardization of the rotation procedures for members of ships' crews under COVID-19 pandemic conditions. The empirical sources of the research comprise relevant acts of international intergovernmental organizations and national administrative restrictions undertaken in 2020 and 2021 at the pandemic outbreak. Systematization of ways and means to ease seafarers' access to complete information on crew changes in different seaports is also made.

\section{The COVID-19 pandemic and seafarers' well-being}

The merchant fleet is the primary driver of contemporary international trade. Nowadays, the vast majority of all world's goods and products are transported by sea: from liquefied gas and oil products to medical face masks and patches, vehicles and fruit. The seafarers' labor market has over 1,5 million vacancies and may be compared with the population of a small European country. Due to the IMO data about 150.000 seafarers need to be changed every month (IMO Circular Letter No. 4204/Add.14). After the crew change issue extending to about 200.000 seafarers stuck on ships in the spring of 2020, national and international organizations have started creating updates for standard rotation protocols.

In general, the crew rotation issue received a multilevel response:

- at the level of global governance, specialized UN agencies, the IMO, ILO, WHO, and ICAO, jointly act to ensure the provision of adequate guidance to governments and the maritime industry;

- at the national level, governments of particular countries take efforts to enable seafarers to disembark for medical care and transfer and transit to their home countries;

- the stakeholders in the maritime industry, including the International Chamber of Shipping (ICS) and the ITF, have provided common guidance for shipowners and seafarers, recommendations for governments, and relevant national authorities (Doumbia-Henry, 2020). 
However, despite all efforts, by March 2021, rates have returned to the numbers from about a year ago (Concerns of rise in number of seafarers impacted by crew change due to new COVID-variants; Crew change crisis is far from over and issues around vaccination need to be resolved). Nevertheless, it has not entirely resolved the problem, as in 2021, world ports started closing down again and imposing administrative restrictions because of new COVID-19 variants, which appear to be more contagious. Due to the latest data on mid of June 2021 the number of seafarers onboard vessels beyond the expiry of their contract has continued rising from $7.2 \%$ to $8.8 \%$ and the number of seafarers onboard for over 11 months has risen from $0.4 \%$ to $1 \%$ comparing to previous month (Crew Change Indicator, 2021).

International maritime traffic has always relied on the international workforce. Since time immemorial, States have recognized the unique nature of the seafaring profession, accorded the facility of transit and transfer to seafarers (Malhotra, 2007, p. 17). Reinforced administrative restrictions: quarantine and sanitary measures, lockdowns, border crossing bans, sea- and airport closures have become an insurmountable obstacle for traditional crew changes. Occasional ports that allowed access imposed a mandatory twoweek quarantine rule for the arrived seafarers. Moreover, a limited number of open airports were the only opportunity to return home (Chervonenko, 2020).

Expired contracts, restrictions on going ashore, long-term stay in small communities, and increasing fatigue have caused apparent challenges to the stability of seafarers' emotional conditions. The human element is known to cause an overwhelming number of maritime accidents. The human error was recognized to result in the recent incident with the ship Ever Given in the Suez Canal (Suez Canal Chief Says Human Error is to Blame for Ever Given Fiasco). Navigational Safety is directly dependent on human intellectual, physical, emotional capabilities. Thus, it is critical to ensure the 
quality of living conditions, working and leisure facilities, health care of each crew member. Moreover, when it became virtually impossible in 2020 to change crews after completing their contracts on ships in a reasonable time and providing essential medical services in ports has become a problem, the worldwide shipping industry encountered a humanitarian disaster. Its spreading became threatening not only for ensuring maritime safety but for the whole international delivery system. Among such goods, under pandemic conditions, a significant share consisted of essential items, which could jeopardize social stability and health of the population throughout the world. Thus, at least 155 million people in 55 countries worldwide were severely food-insecure during the past year - that is 20 million more than the year before. This number has increased dramatically, partially due to economic shocks related to pandemic ( 155 million faced acute food insecurity in 2020, conflict the key driver).

Due to the current research the issue of crew rotations has two major types of consequences:

- on the one hand prolonged working periods on-board threaten mental, physical and social well-being, which may reflect on the overall health, work engagement and safety of seafarers;

- on the other hand, impossibility to rotate to vessels threats economic well-been of seafarers (Sliskovic, 2020, p. 808).

The exposure of seafarers to the substantial influence of restrictive measures has made their labor significantly more complex. Nevertheless, they continued to serve globally significant and responsible functions. The seafarers' critical role in ensuring global trade, maritime security, environmental protection, and value of their dedicated work got global designation by the International Maritime Organization. The Day of the Seafarer, which IMO carries out, was entitled "\#SeafarersAreKeyWorkers" (Lim, 2020) in 2020 (25 June), and the World Maritime Day 2021 (30 September) will be devoted to the topic "Seafarers: at the core of shipping's future" (IMO announces World Maritime Theme for 2021). 
Herewith, as of 7. April 2021, 55 countries and two associate members IMO designated seafarers as key workers (Crew changes: A humanitarian, safety and economic crisis; Concerns of rise in number of seafarers impacted by crew change due to new COVID-variants). Such recognition helps seafarers to overcome administrative restrictions and ensure the stability of maritime supply chains, including medical goods. Furthermore, many states have failed to meet standards under Maritime Labour Convention 2006 , and other international instruments of social standards on crew rotations, maximum contract duration, access to medical care, and shore leave. Today ensuring the standards under this Convention to the full extent is the main objective for its members, and for those countries that have not joined it yet, - to protect their citizens and to create the necessary conditions for them to fulfill professional, crucial for modern world tasks comfortable and safe.

\section{Efforts of international organizations to stabilize the crew rotation processes}

The acts and other instruments of international intergovernmental and non-governmental organizations in the area of combating the spreading of the disease in the maritime sector were focused on creating unified lists of ports, where crew changes were possible, and developing the protocols to ensure their epidemiological safety, minimize the negative impact of the humanitarian crisis in the industry. They have become a set of recommended administrative restrictions and best practices for preventing the spread of the pandemic in the industry. For instance, in Circular Letter No.4204/Add.30 from September 11, 2020, ILO, UNCTAD, IOM, FAO, OHCHR, ICAO, the United Nations Global Compact, IMO have jointly issued the statement urging all States to act on urgent resolving the crew change crisis and a humanitarian disaster that will also affect the safety of shipping, the protection of the marine environment, the continuation of efficient trade 
and the recovery of the world economy. The Circular Letter has proposed many actions for stabilizing the rotation situations. Sixteen paragraphs contain recommendations on consultations, implementation of protocols on crew changes, recognizing the key role of seafarers, and allowing them to transit through territories of States and returning home.

Protocols on crew changes contain recommendations for maritime administrations and other relevant national authorities (healthcare authorities, customs offices, immigration, border services, seaport authorities, civil aviation companies). They relate to the roles of shipping companies, their agents, and representatives, including agencies recruiting crews and seafarers, and extend to seaports, airports, and airlines, involved in crew change operations. The Circular Letter No.4204/Add.38 from March 25, 2021, reaffirmed the key role of seafarers in the global economy; and focused the attention on the need to provide their safe and unimpeded movement across national borders, together with granting privileges in the case of COVID-19 vaccination. In addition, the commitment of leading international institutions (ICAO, IMO, WHO, ILO, IOM) to the idea of needing to develop the international harmonized system of vaccination certificates was emphasized.

Meanwhile, in early March 2021, it was noted that the introduction of the vaccine passports could cause two kinds of results in maritime traffic: both to simplify life for many seafarers and to result in inequalities among them, without eliminating the existing problem of crew changes. In a situation like this, seafarers will be divided into two groups: 1) those who will no longer face difficulties in signing off and quarantine restrictions in ports; 2) those who will not have the possibility to receive vaccinations and relevant documents (COVID-passport - a direct path to descrimination and violation of the rights of seafarers?). In this regard 6 April 2021, WHO spoke against COVID-passports implementation to allow a person to enter or leave a country (WHO does not back vaccination passports for 
now: spokeswoman). In February, the Cypriot maritime authorities proposing a global approach to delivering COVID-19 vaccinations to seafarers as part of an effort to help alleviate the global crew change crisis. Meantime indicates the specific process of obtaining doses of vaccine and focuses on separating seafarers into two groups based on the duration of the sea voyage (seafarers that work on shortsea routes and seafarers in deep-sea shipping) (Cyprus Proposed Program to Prioritize COVID Inoculations for Seafarers).

Ingeneral, the "anti-COVID-19" set of internationaldocuments and institutional tools includes a substantial number of the recommended practices. Moreover, during the IMO round table in February 2021 (involving representatives from States in the region, UN agencies, the shipping industry, the relevant trade union organization, and the Pacific Islands Forum), it was suggested to create hub ports for crew changes and repatriation in the Pacific region. Seafarers from the countries of the region faced significant challenges in repatriating. As possible, hubs for change and repatriation of seafarers in the Pacific region were considered ports of Fiji, New Zealand, and Brisbane, Australia. Meeting attendees also suggested the idea of developing a standard protocol for port hubs (Pacific hub ports concept explored for regional crew change and repatriation).

Also, given the challenges related to the psychological condition of seafarers and a significant increase in complaints of suicidal thoughts recorded last year (Bakhsh, 2020) it was proposed to amend the ILO 2006 Convention the necessity to obligatory inform about seafarers' suicides (Bush, 2021).

\section{National and regional experience in counteracting COVID-19 while carrying out crew rotations}

The COVID-19 pandemic is unfolding unevenly across the globe; cases dramatically increase in some areas and decrease or stabilize in others (Santana et al., 2021). The initial disease outbreak in China significantly affected the emergence and implementation 
of unprecedented protective measures throughout South-East Asia. Meanwhile, States of this region were the first (Foo-Nielsen, 2020) to ease administrative quarantine restrictions. However, it turned out to be premature and has caused an increase in the spread of disease in the sector. Thus, a worsened epidemiological situation in Hong Kong was associated with the abolition of 14-day quarantine for the "required staff" (crew members for the aircraft and merchant ships, specific categories of drivers). Consequently, at the end of July 2020, Hong Kong authorities were forced to establish an administrative ban on crew changes. This rule did not address only vessels heading directly in Hong Kong, but their crews had to immediately move either to the airport or to the quarantine center (Hong Kong Suspends Crew Changes Except for Cargo Ships in Port). Strengthened administrative restrictions in different combinations were also imposed in the summer of 2020 in Malaysia and Singapore (Crew Changes \& COVID-19 in Malaysia; Gu, 2020), which caused a new kind of conflict with a crew change. One way of resolving this situation had become the permission of certain countries (India, Thailand) to use their territory for transit of seafarers, who completed their contracts, but in exchange for employing their citizens (Voytenko, 2020). Such an alternative has, however, found no support.

In general, by May 2020, under the rapidly spreading pandemic, crew changes were strictly forbidden in 87 out of 135 countries. Only Canada, Denmark, Finland, Germany, Iceland, Southern Ireland, and Sweden consider the possibility of an official and safe crew change. In many other countries, rotations were allowed, but with limitations, based on complex and challenging conditions, and even each case was still considered separately and individually (Ukraine have joined the list of countries where crew change is prohibited). By the end of May 2020, countries allowing crew changes amounted to 25 . Restrictions depending on travel history were imposed in 17 , and crew change is prohibited, or borders are closed in 58 counties (Crew change: Where it is allowed and where it is not). 
Europe also faced crew change problems, but thanks to rapid response and securing the necessary conditions of rotations, particularly European ports remained open at the most challenging times. In Portugal, requirements for crew changes have been limited to the availability of valid (for the last 72 hours) negative tests for COVID-19 (for non-EU seafarers). The seafarers from the EU were encouraged to take the test in their country of origin. In case of a negative result, quarantine had been lifted (Global Crew Change Advice, p. 87-88). In Denmark, crew rotations for cargo vessels were allowed if there were no signs of disease, and after providing documentary evidence, the seafarer is taking the ship and not staying in Denmark (Corona/COVID-19). Ukraine imposed an absolute prohibition on crew changes. Rotation under lockdown 2020 was possible just for its citizens (Imprisoned by the virus: crew change has been indefinitely postponed).

In the USA, crew changes were allowed, but with considerable administrative restrictions:

- foreign crew members had to fly in one of the 13 airports (Hartsfield-Jackson Atlanta International Airport (ATL), Boston Logan International Airport (BOS), Chicago O'Hare International Airport (ORD) etc.).

- they are not supposed to have COVID-19 symptoms.

- there is a 14-day quarantine for ships and crews.

- crew change was possible and was considered individually at specified ports in the USA (Global Crew Change Advice, p. 122-123).

The countries of Latin America revealed in 2020 substantial progress in administrating crew changes. A compilation of the best port practices for work under special pandemic conditions was made at the initiative of the Brazilian Port of Açu (WPSP COVID-19 Guidance Document for Ports). Chile was one of the first to fulfill the requirements of ILO protocol on a safe crew change. Foreign crew members were officially allowed to enter the country through the airports to maintain supply chains (Labrut, 2020). 
In Panama's ports, all seafarers should provide PCR-COVID-19 negative test results made within 72 hours before landing. Seafarers were exempted from 14-day quarantine. When there was no test, express testing needed, and if a positive result, the seafarer was to be quarantined. The Panamanian authorities also demanded special notification ten days prior to the ship's arrival or scheduled crew change date (Crew Change During COVID-19).

In Australia, crew changes were allowed with limitations: seafarers can go ashore at ports; quarantine was not required, replaced with the self-isolation period; additional governmental and territorial control may be performed. Besides, it was necessary to get permission for a crew change from a vast number of parties, authorities, and service providers; each rotation situation was subject to consideration separately (Covid-19 - Federal Restrictions. Australian Federal Restrictions).

Therefore, the majority of administrative restrictions for rotations of crew members in ports worldwide included the necessities to:

- get the necessary medical treatment in the embarking country or fill in the health declaration form;

- dockage during the crew change off the port;

- to ensure the existence of social distancing; strict control over health, including recurrent measuring of temperature; negative coronavirus test result; engagement letter from an authorized about the crew heading from the airport right to the ship (or from the ship to the airport); detailed transportation plan; written evidence of a valid excuse for change before expiration of the contract (death of a close relative, etc.);

- to confirm: being quarantined; staying on board within a given period (generally - at least 12 months).

In September 2020, IMO recommended (Resolution MSC.473(ES.2) that States designate National Focal Points on Crew Change and Repatriation of Seafarers to coordinate action at a national level. Such points were designated in many countries 
worldwide (Australia, Cyprus, the Bahamas, Brazil, Canada, etc.) (MSC.7/Circ.1/Rev.24). Thanks to their work on the establishment of rotation mechanisms and implementation of best practices in ports worldwide, the tension with crew changes was managed to decrease by the beginning of 2021. In 2021 many countries have initiated vaccine passports, and Several companies have announced access to ships only for passengers and crew members who were vaccinated and can verify that.

In early 2021 countries have started increasing administrative restrictions again and prohibited crew changes in their ports (the Philippines (Memorandum Circular No. 2021-03), Singapore (Port Marine Circular No. 02 of 2021) etc.), publishing the list of countries whose citizens were not allowed to change. In addition, it was acknowledged that since the new, more dangerous COVID19 variant is still spreading, such lists can be extended. Singapore has tightened the testing procedures for all shore-based personnel, Indian authorities proposed to their Chinese counterparts facilitating a crew change at sea (India Proposes Crew Change at Sea for Ships Stranded off China), and the quarantine isolation of the seafarers has been implemented on a cruise ship in Sri Lanka (Nadkarni, 2021). In doing so, the requirements familiar from 2020 regarding using of protective masks, maintaining the safety distance and anti-epidemic measures remained. The Indian coronavirus strain, Increased risk of morbidity and mortality, associated communicable diseases in the region in May 2021 had a significant impact on imposing administrative restrictions in ports. Thus, the Philippines, Fujairah, Singapore, and Hong Kong have restricted crew changes for seafarers coming from Indian sub-continent nations 14 days before entering their ports (Philippines bans international crew change for vessels arriving from seven countries).

In March 2021, the United Kingdom started the gradual easing of restrictions. The UK Department for Transport announced that all seafarers, irrespective of nationality, will be exempted from Red 
List country restrictions, most notably mandatory hotel quarantine, with effect from 19 March 2021 (Seafarers entering the UK will be exempted from quarantine rules).

In Canada, according to the Ship Safety Bulletin (SSB) No.03/2021, there is no requirement for seafarers to provide a negative COVID-19 test result, and quarantine is canceled for them. They should not have the symptoms of the disease, however. Even though main administrative restrictions have been generally lifted from maritime workers, they still need to keep to some regional prohibitions (including the potential quarantine), provide similar medical and contact information.

The easing of restrictions is much more complex in Norway. The system implies that seafarers in transit traveling directly from the airport (or other places) are exempt from entry quarantine, provided that the vessel leaves the Norwegian port immediately. The quarantine is unnecessary if a seafarer has a negative COVID-19 result in two tests made within 24 hours after arriving in the country. The compulsory isolation does not apply to the seafarers of a vessel scheduled to leave a Norwegian port within three days and will not call at a Norwegian port within ten days after departure. Furthermore, the crews that have not changed their members in foreign ports are exempt from quarantine (Guidelines for crew changes in Norway during the COVID-19 pandemic).

\section{Maritime industry stakeholders and global administration of information exchange}

The law is typically slow to respond to changes in public life. The advent of the novel coronavirus disease (COVID-19) appears to be an exception to the rule (Muller, 2021, p. 107). Responses of parliaments and governments, civil society institutions, and industry associations allowed in 2021 to finally find solutions to the complex rotation situation. For example, the rapid response was provided by the International Association of Ports and Harbors within 
the frameworks of World Ports Sustainability Program issuing the guidance for port authorities and port operators (Faqiang \& Abliakimova, 2020, p. 26).

International Chamber of Shipping (ICS) has taken prompt actions to ensure industry functioning in the face of the pandemic, which includes several essential steps:

- ICS organized a vital platform for discussion between the industry and international organizations on Coronavirus related issues;

- ICS, in collaboration with relevant UN agencies, produce guidance for the industry and governments, distributed by IMO;

- ICS brought together members of the shipping industry to ensure crew changes could occur at regular group meetings, including a Coronavirus Strategy and Welfare Group, a Crew Change Taskforce (COVID-19: A year on);

- ICS is collecting information on the ability of ships to conduct crew changes to encourage states to implement the 'IMO Protocols' and facilitate crew changes (COVID-19-Calling shipping companies or masters to fill in the crew change report form).

A vital attempt of joining the maritime industry's efforts has become "The Neptune Declaration on Seafarer Wellbeing and Crew Change", which was opened for signature in December 2020 and up to June 2021 has been signed by more than 800 organizations. The core idea of the Neptune Declaration is based on the recognition of the shared responsibility of stakeholders, organizations, and governments to resolve the crew change crisis by implementing solutions that work in practice.

The Neptune declaration suggests four main actions to address the crew change crisis that should be implemented:

- recognize seafarers as key workers and give them priority access to Covid-19 vaccines;

- establish and implement gold standard health protocols based on existing best practices; 
- increase collaboration between ship operators and charterers to facilitate crew changes;

- ensure air connectivity between key maritime hubs for seafarers.

The Neptune Declaration provides additional resources to cope with the crew changes crisis. The Neptune Declaration Crew Change Indicator, which is published monthly, provides up-to-date information on the crew change situation, including the percentage of seafarers onboard beyond the expiry of their initial contracts and the percentage of seafarers who have been onboard over 11 months. The Neptune Declaration Best Practices for Charterers focuses on inspiring charterers to implement others' best practices in the field and to share their own best practices openly (The Neptune Declaration Best Practices for Charterers).

Besides, during the past year, many instruments on information support heling to keep track of restrictions on vessels and crew worldwide emerged due to actions of global shipping companies and related businesses. Associations, like chambers of shipping, usually endorse such efforts. For example, the UK Chamber of shipping recommends that its members use the "COVID19 global port restrictions map" produced by Wilhelmsen Ship Services, providing a link to it on its official website (COVID19 global port restrictions map). Similar instruments to aggregate Coronavirus-related restrictions affecting crew changes can be found in a number of maritime businesses under different names, like "Coronavirus (COVID-19), restrictions at Ports/Countries", "GMS \& Immigration COVID-19 Global Tracker" (Flash Alerts - COVID-19).

Nevertheless, the maritime industry requires enhancing information support towards crew changes and respective rights of seafarers. For example, the research suggests that only about $70 \%$ of seafarers have full awareness of the international regulations pertaining to shore leave, repatriation, and medical assistance. 
Many such instruments require attentiveness, taking into account the stability/instability of registering up-to-date information in them. However, stakeholders' efforts apparently lack imperative rules that might impose obligations on submitting relevant information in a timely manner. Besides, there are much broader possibilities to use information technologies in counteracting the challenges of the COVID-19 pandemic. For example, it is believed that effective Port State Inspections based on IMO conventions and big data applications could reduce potential operation risk and provide successful turnaround opportunities (Yazir et al., 2020). Besides, development of the information management in the field including above mentioned digital solutions should not be viewed as a temporary measure, rather as a new regime that very likely may become a business of usual. The transition to a new normality requires improvement of global-level anticyclical management institutions, which should be facilitated by these components of pandemic management (Poruchnyk et al., 2021, p. 411).

For the maritime industry unified information platform may become effective, created under the IMO aegis. Its operation's beginning has become a new module in the Global Integrated Shipping Information System (GISIS). Early in April 2021, IMO has issued a relevant circular (No. 4398, 8 April) (Foo-Nielsen, 2021). It contains information already available and permits Member States to enter the information, on national focal point of contact for crew change and repatriation of seafarers. However, Circular Letter No.4398 from 8 April 2021 does not define mandatory requirements for entering the relevant information. In our opinion, for the approved IMO national maritime administrations (The national Administrator for IMO Web Accounts) except for authorized access to the system should be provided, the responsibility of daily updates and management system of control with the possibility for implementation of sanctions in the form of detentions in the procedures of Port State Control. 


\section{Conclusions}

Easing and lifting the pandemic-related administrative restrictions affecting crew changes is an essential task of ensuring the effective functioning of the maritime industry and securing supply chains. The global essence of the issue demands a multilevel approach and joining efforts of international organizations, national governments, and industry stakeholders. The leading role in simplifying present rules is performed by the soft law sources, such as common recommendations and sharing best practices. Besides, the important way to facilitate flawless crew changes' processes consists in utilizing information technologies both by the public and private actors. Even the easing of administrative restrictions does not return well-been of vessels crews to the pre-pandemic times; thus, the industry should have long-term plans to adopt the new-normal working environment.

\section{REFERENCES}

155 million faced acute food insecurity in 2020, conflict the key driver. UN News. https://news.un.org/en/story/2021/05/1091302

Bakhsh, N. (2020). Crew calls to helplines jump amid health crisis. Lloyd's List. https://lloydslist.maritimeintelligence.informa.com/LL1133534/Crew-callsto-helplines-jump-amid-health-crisis

Burns, J. et al. (2021). International travel-related control measures to contain the COVID-19 pandemic: a rapid review. Cochrane Database of Systematic Reviews, 3. Art. No.: CD013717. DOI: 10.1002/14651858.CD013717.pub2

Bush, D. (2021). Suicides at sea go uncounted as crew change crisis drags on. Lloyd's List. https://loydslist.maritimeintelligence.informa.com/LL1135870/ Suicides-at-sea-go-uncounted-as-crew-change-crisis-drags-on

Chervonenko, V. (2020). How Minsk has become a bailout hub for the Ukrainians stuck abroad. BBC News. Ukraine. https://www.bbc.com/ukrainian/featuresrussian-52633464 [in Russian].

Concerns of rise in number of seafarers impacted by crew change due to new COVID-variants. The web-site of the International Chamber of Shipping. https://www.ics-shipping.org/press-release/concerns-of-rise-in-number-ofseafarers-impacted-by-crew-change-due-to-new-covid-variants/ 
Corona/COVID-19. Danish Maritime Authority. https://www.dma.dk/Presse/ temaer/corona/Sider/default.aspx

Coronavirus (COVID-19) - Joint Statement calling on all Governments to prioritize COVID-19 vaccination for seafarers and aircrew. Circular Letter No.4204/Add.38 from March 25, 2021. The official website of the International Maritime Organization. https://cutt.ly/6nACsYQ

Coronavirus (COVID-19), restrictions at Ports/Countries. Waypoint Port Services. https://www.waypointports.com/covid-19/

COVID-19: A year on. Shipping has proven resilient through the pandemic but challenges of crew change and vaccine passports continue. International Chamber of Shipping. https://www.ics-shipping.org/news-item/ covid-19-a-year-on/

COVID-19 - Calling shipping companies or masters to fill in the crew change report form. International Chamber of Shipping. https://www.ics-shipping.org/news-item/covid-19-crew-change-form/

Covid-19-Federal Restrictions. Australian Federal Restrictions. Shipping Australia Limited. https://www.shippingaustralia.com.au/covid-19-shipping-update/ covid-19-federal-restrictions/

COVID-19 global port restrictions map. UK Chamber of Shipping. https://www.ukchamberofshipping.com/coronavirus-covid-19-update/covid19-global-port-restrictions-map/

COVID-19. Crew change crisis 2021. http://assol.org.ua/2021/01/04/covid-19krizis-smen-ekipazha-2021/ [in Russian].

COVID-passport - a direct path to descrimination and violation of the rights of seafarers? https://www.seafarersjournal.com/abroad/covid-pasport-pryamojput-k-diskriminatsii-i-narusheniyu-prav-moryakov/ [in Russian].

Crew change crisis is far from over and issues around vaccination need to be resolved. The official web-site of the International Maritime Organization. https://www.imo.org/en/MediaCentre/PressBriefings/pages/Crew-changeCOVID-19.aspx

Crew change crisis risks becoming forced labour epidemic as tragedy hits sixmonth mark on World Maritime Day. Press release. https://www.itfglobal.org/ en/news/crew-change-crisis-risks-becoming-forced-labour-epidemic-tragedyhits-six-month-mark-world

Crew Change During COVID-19. Autoridad Maritima de Panama. https://amp.gob.pa/crew-change-during-covid-19/ 
Crew Change Indicator (2021). The Neptune Declaration. https://www.globalmaritimeforum.org/content/2021/06/The-NeptuneDeclaration-Crew-Change-Indicator-July-2021.pdf

Crew change: Where it is allowed and where it is not. https://cutt.ly/yvD1Gy2

Crew changes: A humanitarian, safety and economic crisis. https://www.imo.org/ en/MediaCentre/HotTopics/Pages/FAQ-on-crew-changes-and-repatriation-ofseafarers.aspx

Crew Changes \& COVID-19 in Malaysia. GAS. https:/www.gac.com/ news--media/corporate-news/crew-changes--covid-19-in-malaysia/

Cyprus Proposed Program to Prioritize COVID Inoculations for Seafarers. The Maritime Executive. https://www.maritime-executive.com/article/ cyprus-proposed-program-to-prioritize-covid-inoculations-for-seafarers

De Beukelaer, Ch. (2021). COVID-19 at sea: 'the world as you know it no longer exists'. Cultural Studies, 35, 2-3, 572-584. DOI: $10.1080 / 09502386.2021 .1898020$

Doumbia-Henry, C. (2020) Shipping and COVID-19: protecting seafarers as frontline workers. WMU Journal of Maritime Affairs, 19, 279-293. DOI: $10.1007 / \mathrm{s} 13437-020-00217-9$

Faqiang, L., \& Abliakimova, E. (2020). Safe ports: law, theory, practice under conditions of the COVID-19 pandemic. Lex Portus, 4, 7-34. DOI: $10.26886 / 2524-101 X .4 .2020 .1$

Flash Alerts - COVID-19. KMPG. https:/home.kpmg/xx/en/home/insights/ 2020/03/flash-alert-covid19.html

Foo-Nielsen, A.C. (2020). China opens up 10 ports for foreign crew change and implements a circuit-breaker mechanism. Bimco.org. https://www.bimco.org/ news/ports/20201012-china-opens-up-10-ports-for-foreign-crew-change

Foo-Nielsen, A.C. (2021). Crew change and repatriation of seafarers - IMO establishes new module on GISIS. Bimco.org. https://www.bimco.org/news/ ports/20210412-gisis-new-module-on-crew-change-and-repatriation

Global Crew Change Advice. Version 1.9. Release: February 2021. Bimco.org

$\mathrm{Gu}$, V. (2020). New Covid-19 cases prompt Singapore crew change action. Argusmedia.com. https://www.argusmedia.com/en/news/2126093new-covid19-cases-prompt-singapore-crew-change-action

Guidelines for crew changes in Norway during the COVID-19 pandemic. The website of the Norwegian Maritime Authority. https://cutt.ly/UnACfIy 
Hong Kong Suspends Crew Changes Except for Cargo Ships in Port. The Maritime Executive. https://www.maritime-executive.com/article/hong-kongsuspends-crew-changes-except-for-cargo-ships-in-port

ILO. (2006, February 23). Maritime Labour Convention. https://cutt.ly/cmjv3FD

IMO. (2020, May 5). Coronavirus (COVID-19)-Recommended framework of protocols for ensuring safe ship crew changes and travel during the coronavirus (COVID-19) pandemic: Circular Letter (No. 4204/Add.14). https://cutt.ly/JmjsIhj

IMO. (11 September 2020). Coronavirus (COVID-19) - Joint Statement calling on all Governments to immediately recognize seafarers as key workers, and to take swift and effective action to eliminate obstacles to crew changes, so as to address the humanitarian crisis faced by the shipping sector, ensure maritime safety and facilitate economic recovery from the COVID-19 pandemic: Circular Letter (No.4204/Add.30). https://cutt.ly/rmjvCBZ

IMO announces World Maritime Theme for 2021. Shipping and Freight Resource. https://cutt.ly/amjst4M

Imprisoned by the virus: crew change has been indefinitely postponed. The Shipping. https://sudohodstvo.org/v-plenu-u-virusa-smena-ekipazhejotkladyvaetsya-na-neopredelennyj-srok/ [in Russian].

India Proposes Crew Change at Sea for Ships Stranded off China. Maritimeexecutive.com. https://www.maritime-executive.com/article/india-proposescrew-change-at-sea-for-ships-stranded-off-china

Labrut, M. (2020). Chile to allow international crew change. SeaTrade. Maritime news. https://www.seatrade-maritime.com/regulation/chile-allowinternational-crew-change

Lim, K. (2020). Day of the Seafarer 2020. The official web-site of the International Maritime Organization. https://wwwcdn.imo.org/localresources/en/About/ Events/Documents/Day\%20of\%20the\%20Seafarer\%202020\%20-\%20SG\%20 message.pdf

Malhotra, N. (2007). Balancing seafarers' welfare and maritime security with biometrics. World Maritime University Dissertations. 159. http://commons.wmu.se/all_dissertations/159

MemorandumCircularNo.2021-03.TheInternationalMaritimeEmployers 'Council. http://www.imec.org.uk/wp-content/uploads/2021/01/Philippines-BOQGuidelines-on-the-Issuance-of-BOQ-Certificate-upon-Completion-of.pdf

MSC. (2020, September 21). Recommended action to facilitate ship crew change, access to medical care and seafarer travel during the COVID-19 
pandemic: Resolution MSC.473(ES.2). The International Association of Dry Cargo Shipowners (INTERCARGO). https://www.intercargo.org/wp-content/ uploads/2020/09/Resolution-MSC.473ES.2-on-Crew-Change.pdf

MSC. (2021, February 26). Resolution MSC.473(ES.2) - recommended action to facilitate ship crew change, access to medical care and seafarer travel during the COVID-19 pandemic. National Focal Points on Crew Change and Repatriation of Seafarers: MSC.7/Circ.1/Rev.24. Bimco.org. https://www.bimco.org/news/ports/20210326-bimco-covid-19-weekly-report

Muller, L.S. (2021). COVID-19 Changes in Laws and Regulations. Professional Case Management, 26, 2, 107-110. DOI: 10.1097/NCM.0000000000000491

Nadkarni, S. (2021). Indian cruise ship providing quarantine floatel for Sri Lanka crew change. Seatrade Maritime News. https://www.seatrade-maritime.com/ ship-operations/indian-cruise-ship-providing-quarantine-floatel-sri-lankacrew-change

Pacific hub ports concept explored for regional crew change and repatriation. The website of the IMO. from: https://www.imo.org/en/MediaCentre/Pages/ WhatsNew-1587.aspx

Philippines bans international crew change for vessels arriving from seven countries. Seatrade Maritime News. https://www.seatrade-maritime.com/regulation/ philippines-bans-international-crew-change-vessels-arriving-seven-countries

Port Marine Circular No. 02 of 2021. The International Maritime Employers' Council. http://www.imec.org.uk/wp-content/uploads/2021/01/pc21-02.pdf

Poruchnyk A., Kolot A., Mielcarek P., Stoliarchuk Y., \& Ilnytskyy D. (2021). Global economic crisis of 2020 and a new paradigm of countercyclical management. Problems and Perspectives in Management, 19, 1, 397-415. DOI:10.21511/ppm.19(1).2021.34

Santana, F.N. et al. (2021). A path forward for qualitative research on sustainability in the COVID-19 pandemic. Sustain Sci 16, 1061-1067. DOI: 10.1007/ s11625-020-00894-8

Seafarers entering the UK will be exempted from quarantine rules. Safety4sea.com. https://safety4sea.com/seafarers-entering-the-uk-will-beexempted-from-quarantine-rules/

Sliskovic, A. (2020). Seafarers Well-being in the Context of the COVID-19 Pandemic: A Qualitative Study. Work, 67, 4, 799-809. DOI: 10.3233/ WOR-203333

Suez Canal Chief Says Human Error is to Blame for Ever Given Fiasco.Cukute.com.https://cukute.com/en/suez-canal-chief-says-human-erroris-to-blame-for-ever-given-fiasco 
The Neptune Declaration Best Practices for Charterers. Global Maritime Forum. https://www.globalmaritimeforum.org/neptune-declaration/bestpractices-for-charterers

The Neptune Declaration on Seafarer Wellbeing and Crew Change, 2020. https://www.globalmaritimeforum.org/content/2020/12/The-NeptuneDeclaration-on-Seafarer-Wellbeing-and-Crew-Change.pdf

Ukraine have joined the list of countries where crew change is prohibited. Sekunda. [The second]. https://www.krme.top/?p=10209 [in Russian].

Updated guidance to vessel crew members and non-crew marine sector workers respecting entry into Canada - SSB No.: 03/2021. Government of Canada. https://cutt.ly/wmjdA9Z

Voytenko, M. (2020). Thailand crew change: open for off-sign, but not for on-sign. Fleetmon. Traking the seven seas. https://www.fleetmon.com/ maritime-news/2020/30941/thailand-crew-change-open-sign-not-sign/

WHO does not back vaccination passports for now: spokeswoman. Reuters. https://www.reuters.com/article/us-health-coronavirus-who-vaccines/who-doesnot-back-vaccination-passports-for-now-spokeswoman-idUSKBN2BT158?il=0

WPSP COVID-19 Guidance Document for Ports. World Ports Sustainability Program. https://sustainableworldports.org/wp-content/uploads/2020-05-18WPSP-COVID19-Guidance-FIN.pdf

Yazir, D., Şahin, B., Yip, T., \& Tseng, P-H. (2020). Effects of COVID-19 on maritime industry: a review. International Maritime Health, 71, 4, 253-264. DOI: $10.5603 / \mathrm{IMH} .2020 .0044$

Лученко Д., Георгієвський Ю. Адміністративні обмеження у портах: практика ротацій екіпажів в умовах пандемії COVID-19. - Cтаття.

У статті розглянута динаміка запровадження адміністративних обмежувальних заходів для ротацій екіпажів у портах світу в умовах триваючої пандемії COVID-19. Перша частина статті присвячена короткому оглядові причин і наслідків гуманітарної катастрофи у морській галузі. Відзначено ключову роль моряків у забезпеченні світової торгівлі, безпеки на морі та захисту навколишнього середовища. У другій частині статті охарактеризований національний і регіональний досвід протидії COVID-19 при ротаціях екіпажів, виділені основні тенденції посилення/послаблення обмежень у портах. Узагальнення і аналіз основних адміністративних обмежувальних заходів при ротаціях членів екіпажів дозволили виділити найбільш стандартні з них: проходження необхідних медичних процедур у країні посадки на судно або заповнення медичної декларації, стоянка судна під час зміни 
екіпажу за межами порту, забезпечення соціального дистанціювання, суворого контролю за станом здоров'я і негативного тесту на коронавірус, підтвердження пройденого карантину і перебування на судні упродовж певного періоду. Далі були розглянуті зусилля міжнародних організацій щодо мінімізації впливу пандемії на стабільність змін екіпажів у портах. Серед рекомендованих заходів були запропоновані організаційні та правові механізми спрощення і сприяння стабільній та безперешкодній зміні екіпажів. Аналіз уніфікації процедур ротації та глобального адміністрування механізмів отримання інформації про них засвідчив наявність значного масиву узагальнень, рекомендацій наднаціональних інституцій і внутрішньодержавних процедур. Відсутність на певному етапі зведеної інформації про всі адміністративні обмеження найбільших портів світу стало складною проблемою. Вона частково вирішена сьогодні, проте вимагає більшого імперативного регулювання: закріплення обов'язку щоденного оновлення інформації державами і запровадження системи контролю з можливістю застосування санкцій у вигляді затримань суден відповідно до процедур Port State Control.

Ключові слова: адміністративні обмеження, морські порти, пандемія COVID-19, ротації членів екіпажів, гуманітарна криза, порти-хаби.

\section{Лученко Д., Георгиевский Ю. Административные ограниче-} ния в портах: практика ротаций экипажей в условиях пандемии COVID-19. - Статья.

В статье рассмотрена динамика введения административных ограничительных мер для ротаций экипажей в портах мира в условиях длящейся пандемии COVID-19. Первая часть статьи посвящена краткому обзору причин и последствий гуманитарной катастрофы в морской отрасли. Отмечена ключевая роль моряков в обеспечении мировой торговли, безопасности на море и защите окружающей среды. Во второй части статьи охарактеризован национальный и региональный опыт противодействия COVID-19 при ротациях экипажей, выделены основные тенденции усиления/ослабления ограничений в портах. Обобщение и анализ основных административных ограничительных мер при ротациях членов экипажей позволили выделить наиболее стандартные из них: прохождение необходимых медицинских процедур в стране посадки на судно или заполнение медицинской декларации, стоянка судна во время смены экипажа за пределами порта, обеспечение социального дистанцирования, строгого контроля за состоянием здоровья и отрицательного теста на коронавирус, подтверждение пройденного карантина и пребывания на судне в течение определенного периода. Далее были рассмотрены усилия международных организаций по минимизации влияния пандемии на стабильность смен экипажей в портах. Среди рекомендованных 
мер были предложены организационные и правовые механизмы упрощения и содействия стабильной и беспрепятственной смене экипажей. Анализ унификации процедур ротации и глобального администрирования механизмов получения информации о них показал наличие значительного массива обобщений, рекомендаций наднациональных институций и внутригосударственных процедур. Отсутствие на определенном этапе сводной информации о всех административных ограничениях крупнейших портов мира стало сложной проблемой. Она частично решена сегодня, однако требует бо́льшего императивного регулирования: закрепления обязанности ежедневного обновления информации государствами и введения системы контроля с возможностью применения санкций в виде задержаний судов при процедурах Port State Control.

Ключевые слова: административные ограничения, морские порты, пандемия COVID-19, ротации членов экипажей, гуманитарный кризис, порты-хабы. 